\title{
MONSEÑOR CARO Y EL APOSTOLADO FAMILIAR EN TARAPACÁ
}

(1911-1926)

\author{
POR
}

VALESKA TRONCOSO ZÚÑIGA

Profesora de la Escuela de Educación de la Universidad Santo Tomás, Chile

\section{RESUMEN:}

El presente artículo analiza el apostolado familiar de José María Caro en el Vicariato Apostólico de Tarapacá entre los años 1911 y 1926. En este análisis la autora pone énfasis en su labor misional y cómo a través del cristianismo práctico diseña e implementa una reforma integral de la familia tarapaqueña.

\section{PALABRAS CLAVES:}

Iglesia - Acción Social - Historia de Chile - Siglo XX.

\section{MONSIGNOR CARO AND FAMILIAR APOSTOLATE IN TARAPACA}

(1911-1926)

\section{ABSTRAC:}

The article analyzes the familiar apostolate of Jose Maria Caro in the Vicarship of Tarapaca between the years 1911 and 1926. In this analysis the author puts emphasis in José María's job as a missionary and how through the practical Christianity he is able to design and implement an integral reform in the tarapaqueña family.

KEYWORDS:

Church - Social Action - History of Chile - 20th century.

Recibido/Received: $\quad$ 01-11-2011 Aceptado/acceptd 30-10-2013 
La familia se ha configurado, a lo largo de la historia, como uno de los temas de gran importancia para la Iglesia Católica, al ser reconocida como el fundamento de la sociedad humana, sobre la que descansan todas las instituciones creadas por el hombre. Este reconocimiento ya se hacía evidente hacia fines del siglo XIX, en momentos que el catolicismo social emprendía sus primeros pasos en varios países de Europa, como expresión de un profundo replanteamiento de la percepción de la realidad social por parte de los católicos y principalmente de las implicancias de la fe cristiana en el orden social. ${ }^{1}$ En este sentido, destaca la idea que la recta y ordenada constitución familiar contribuía a la prosperidad de los pueblos, ${ }^{2}$ determinando así, que el orden familiar era un requisito sine qua non del orden social.

El apostolado social será un elemento que definirá el accionar de la Iglesia Católica desde finales del siglo XIX, subrayando los principios generales en la construcción de un orden social y político justo, lo que llevará a sacerdotes y laicos a iniciar la proyección de la Doctrina Social contenida en la Encíclica Rerum Novarum, traduciéndose en un cristianismo de vanguardia, en una pastoral apologética y un nuevo énfasis en la concepción de la Iglesia como Cuerpo Místico de Cristo $^{3}$. El apostolado sacerdotal y jerárquico, irá adquiriendo en lo social, una nueva dimensión de la evangelización de la sociedad moderna, ${ }^{4}$ al mismo tiempo que se comienza a comprender los problemas sociales ya no sólo como propios de algunos individuos, sino que como síntomas de una crisis que afectaba a toda la sociedad. Por tanto, los problemas sociales no eran tema sólo de los más desprotegidos, sino que involucraban a toda la sociedad, la cual demandaba soluciones integrales. ${ }^{5}$

En Chile, se buscará en el catolicismo europeo una fuente de inspiración y a la vez, se iniciará un proceso de recepción de ideas y ejemplos de modelos de reforma social ${ }^{6}$, por lo que no es de extrañar que la primera encíclica social de León XIII provocara un fuerte impacto en el pensamiento

${ }^{1}$ F. Berrios; J, Costadoat; D. García (eds), Catolicismo Social Chileno. Desarrollo, crisis y actualidad: 11. Santiago: Centro Teológico Manuel Larraín, Universidad Alberto Hurtado.

2 León XIII, Pío XI. 1931. Las enseñanzas sociales de la Iglesia: Rerum Novarum y Quadragesimo Anno: 1891-1931: 38 Santiago: Impr. Chile.

${ }^{3}$ Huerta, M.A.1991. Catolicismo Social en Chile: 280. Santiago: Ediciones Paulinas.

${ }^{4}$ Ibídem: 13 y 178.

5 Valdivieso, P. 2006. Dignidad humana y justicia: la historia de Chile, la política social y el cristianismo (1880-1920): 237. Santiago: Ediciones Universidad Católica de Chile.

${ }^{6}$ Silva, F. 1965. "Notas sobre el pensamiento social católico a fines del siglo XIX". Historia, 4: 244-245.

Hispania Sacra, LXV

Extra II, julio-diciembre 2013, 359-386, e-ISSN: 1988-4265, doi: 10.3989/hs.2013.045 
social católico generando una gran difusión y repercusión, ${ }^{7}$ no sólo en el laicado militante ligado a los sectores conservadores, ${ }^{8}$ sino que también en jóvenes sacerdotes que comenzaban su apostolado en momentos que Chile vivía procesos de migraciones rurales, irrupciones ideológicas e inestabilidad del modelo primario-exportador basado en la industria salitrera nortina.

En este contexto, José María Caro, ${ }^{9}$ primero como párroco en el poblado de Mamiña -al interior de la ciudad de Iquique- y posteriormente

${ }^{7}$ Monreal, S. 2009. "Catolicismo en el Cono Sur: genealogía de un ideario", en F. Berrios; J, Costadoat; D. García (eds), Catolicismo Social Chileno. Desarrollo, crisis y actualidad: 30. Santiago: Centro Teológico Manuel Larraín, Universidad Alberto Hurtado.

8 Sobre el papel del Partido Conservador ante la Cuestión Social véase: Stuven, A. 2009. "Cuestión Social y catolicismo social: de la nación oligárquica a la nación democrática", en F. Berrios; J, Costadoat; D. García (eds), Catolicismo Social Chileno. Desarrollo, crisis y actualidad: 47 -82. Santiago: Centro Teológico Manuel Larraín, Universidad Alberto Hurtado.

9 Nació en Pichilemu el 23 de junio de 1866 y falleció en Santiago en diciembre de 1958. Hijo de José María Caro Martínez y Rita Rodríguez Cornejo. A los quince años ingresó al Seminario de Santiago, a la sección "San Pedro Damiano", lugar que albergaba a los hijos de familias cristianas pobres del campo. Luego de cinco años de estudios, llegó a ser el mejor alumno de su clase y escogido para estudiar en Roma. Junto a Gilberto Fuenzalida fueron los primeros alumnos chilenos en el Colegio Pío Latinoamericano. El 20 de diciembre de 1890 fue ordenado sacerdote en la Basílica de San Juan de Letrán, por Monseñor Guilio Lenti y al año siguiente se graduó de doctor en Teología. A su regreso a Chile, se desempeñó como profesor de diversas cátedras de teología dogmática en el Seminario de Santiago entre los años 1892 y 1911. Mientras desarrollaba esta labor, los persistentes problemas de salud lo obligan a buscar un clima que brindara mejores condiciones a sus enfermos pulmones. Es así que solicita al Vicario de Tarapacá Juan Guillermo Carter su traslado a la provincia de Tarapacá. El lugar designado por Carter era el pueblo de Mamiña, al interior de lquique. Pese a que su estadía fue bastante breve, logró impregnar a la población de su palabra evangelizadora. Tras diez meses como párroco de este poblado se ve en la obligación de volver a Santiago ya que los problemas médicos se diversificaron y surgieron otras complicaciones. De vuelta en Santiago fue nombrado viceprepósito de las conferencias morales del clero y publicó su primer libro, El Tratado de los Fundamentos de la Fe. En 1911 es nombrado Vicario Apostólico de Tarapacá y nombrado Obispo en 1912 mientras era Vicario de Iquique. En diciembre de 1925 fue designado Obispo de La Serena, ciudad a la que arribó en 1926. En 1939 fue designado Arzobispo de Santiago para reemplazar a Monseñor José Horacio Campillo, que había renunciado. En 1945 el Papa lo designó Cardenal del Sacro Colegio, con lo cual se convirtió en el primer Cardenal chileno. Sobre la biografía de José María Caro véase: Troncoso Zúñiga, V. 2010. "Un Cruzado en Tarapacá. José María Caro y su gestión pastoral en el Vicariato, 1911-1926", Bicentenario, 9:106109; Mönckeberg Barros, G. 1984. Monseñor José María Caro Rodríguez 19391958. Séptimo Arzobispo de Santiago. Santiago de Chile: Editorial Salesiana; Oviedo Cavada, C. 1979. Los Obispos de Chile, 1561-1978. Santiago de Chile: Editorial Salesiana. 
como Vicario Apostólico de Tarapacá, no se encuentra ajeno a la influencia de las propuestas europeas, enmarcando coherentemente su accionar dentro de una pastoral misional que apuntaba a promover en los obreros del salitre los beneficios morales, sociales y religiosos de la familia bien constituida. Esto porque existía conciencia que la sociedad tarapaqueña vivía graves dificultades que se manifestaban en: "un descontento general en todas las clases sociales: todas sufren, todas se quejan, y son principalmente los obreros los que más alto claman. Por donde quiera que uno vaya se dejan sentir las huelgas, las recriminaciones, las perturbaciones de todo orden". ${ }^{10}$

En investigaciones anteriores ${ }^{11}$ hemos expuesto que su labor en tierras nortinas, sitúa al vicario en el umbral de un catolicismo de corte social, pero paradojalmente esta actitud no ha tenido el reconocimiento que se merece por la historiografía contemporánea, que han puesto énfasis más bien en los aspectos político partidistas, tales como el enfrentamiento del poder político del Partido Conservador, y sus luchas con el Partido Liberal, partidario de la secularización. Un ejemplo claro de ello son los escasos estudios sobre la gestión pastoral del Vicario, los cuales no fueron sino una faceta de lo que sucedía en general, con todo aquello que excediera la historia política y eclesial $^{12}$ y solo intermitentemente, en la década de los 90' del siglo recién pasado, las investigaciones historiográficas sobre el tema empezaron a aparecer con cierto énfasis en lo social. ${ }^{13}$

${ }^{10}$ Las Cuestiones Sociales, 10 de marzo 1921 3:3.

11 Véase: Troncoso Zúñiga, V. 2010:101-124; Troncoso Zúñiga, V. 2012. "el modernismo religioso y la literatura latinoamericana en los albores del siglo XX" en C. Assumma; L. De Llera, La Primera Modernidad: El Modernismo Religioso y Literario en España e Hispanoamérica: 253-276. Bogotá: Editorial Planeta.

12 La producción historiográfica proveniente del mundo eclesiástico se ha caracterizado por centrar su objetivo en exponer al público las virtudes del personaje en estudio. Por esta razón ha desarrollado una mirada edificante de Monseñor Caro, que se enmarcarían dentro del género hagiográfico. Ejemplo de ello son las siguientes obras: Vanherk Moris, J. 1963. Monseñor José María Caro: Apóstol de Tarapacá, Santiago: Del Pacífico; Salinas, A. 1981. Un pastor Santo: el eminentísimo señor cardenal don José María Caro Rodríguez (1866-1958), Santiago: Andrés Bello; Fuenzalida Morandé, J. 1968. El cardenal Caro: autobiografía del eminentísimo y reverendísimo, señor Cardenal D. José María Caro Rodríguez Primer Cardenal chileno: apuntes y recuerdos, documentos importantes, Santiago: Arzobispado de Santiago.

${ }^{13}$ Véase: Michel, J.1989. "La huelga de jornaleros y estibadores de lquique y la participación del presbítero don Daniel Merino Benítez, 1916", Anuario de Historia de la iglesia de Chile, 7: 161-182; García Vázquez, P. 2001. "Pensamiento y desarrollo de la cuestión social en la Iglesia de Iquique, años 1900-1933", Tarapacá, Revista de Historia Regional, 1: 9-24; Castro, L. 2005. "La cuestión social y la visión de la Iglesia Católica de Tarapacá a través del Semanario Las cuestiones sociales (1921-1927)", Revista de Ciencias Sociales, 15: 66-89; Figueroa, C., Silva, B. 2007. Visitas pastorales de las parroquias de la provincia de Tarapacá. José María Caro R. Obispo de Milas y Vicario Apostólico de Tarapacá (1922-1926), Santiago: LOM Ediciones; Troncoso Zúñiga, V. 2010:101-124; Troncoso Zúñiga, V. 2007. José Hispania Sacra, LXV

Extra II, julio-diciembre 2013, 359-386, e-ISSN: 1988-4265, doi: 10.3989/hs.2013.045 
En este artículo analizaremos el apostolado familiar llevado a cabo por José María Caro en la Provincia de Tarapacá, a través del Semanario Las Cuestiones Sociales, publicado por el Vicariato en la ciudad de Iquique y La Revista Católica, órgano oficial de la Iglesia chilena. Durante el periodo en estudio el tema familiar tendrá un rol fundamental puesto que para lograr dar solución a los conflictos sociales que asolaban a la Provincia, la Iglesia Tarapaqueña estima prioritario llevar a cabo una reforma integral orientada a la organización familiar, desarrollando de forma pionera un programa de Acción Social que tiene como base la justicia y la caridad.

\section{EN TIERRA MASÓNICA}

Hacia 1879, con el inicio de la Guerra del Pacífico (1879-1883), el Estado chileno ocupó no sólo militarmente la provincia de Tarapacá- que hasta ese entonces pertenecía a la República del Perú- sino que política y administrativamente comenzó, a partir de 1888, a responder a otra razón y a otro Estado. ${ }^{14}$ Sin embargo, esta provincia, no fue un territorio bajo plena soberanía chilena sino hasta después de la Guerra del Pacífico, en donde a través del Tratado de Paz de Ancón de 1833, la República del Perú, cedía de forma incondicional y perpetua el territorio de la provincia litoral de Tarapacá, cuyos límites comprendían: por el norte, la quebrada y río Camarones; por el sur, la quebrada y río del Loa; por el oriente, la República de Bolivia; y, por el poniente, el mar Pacífico.

María Caro y el Vicariato Apostólico de Tarapacá. Proselitismo, familia y conflicto social (1911-1926), Santiago: Tesis inédita para optar al grado de Licenciada en Historia por la Universidad del Desarrollo.

${ }^{14}$ Garay Vera, C. 2007. "El debate parlamentario sobre las negociaciones con Bolivia entre 1880 y 1904", Cuadernos de Historia, 27:49; González Miranda, S. 2002. Chilenizando a Tunupa. La escuela pública en el Tarapacá andino 1880-1990: 17 Santiago: Ediciones de la Dirección de Bibliotecas, Archivos y Museos DIBAM. 


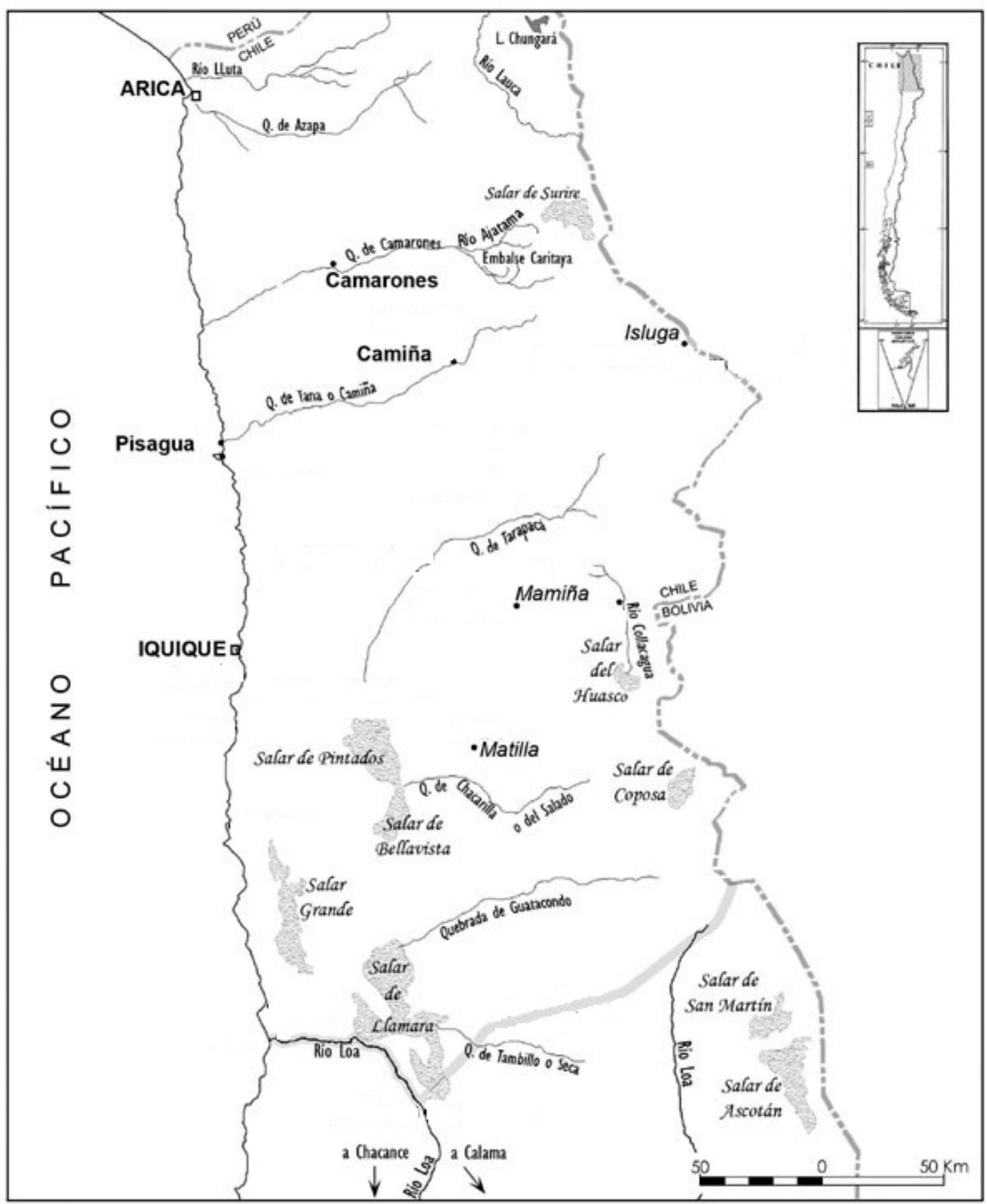

Figura 1. Mapa de las regiones de Arica-Parinacota y Tarapacá, en el que se indican los principales centros urbanos y localidades mencionados en el texto. Uribe, M.; Sanhueza, L.; Bahamondes, F. 2007. "La cerámica prehispánica tardía de Tarapacá, sus valles interiores y costa desértica, norte de Chile (CA. 900-1.450 D.C): Una propuesta tipológica y cronológica", Chungara, Revista de Antropología Chilena, 39: 144. 
La incorporación de la provincia a la soberanía chilena, tuvo una doble implicancia. Por un lado, representó la incorporación de un rico y extenso territorio, permitiendo la ampliación de los límites geopolíticos ${ }^{15}$ y por otro lado, un problema fundamentalmente social y cultural, especialmente en los territorios donde la población originaria era numerosa y mayoritaria. ${ }^{16} \mathrm{En}$ efecto, la riqueza salitrera inaugura el surgimiento de una nueva sociedad en la provincia de Tarapacá, marcada por un gran desarraigo, al ser un espacio transitorio de enganchados o aventureros, que veían en el oro blanco la posibilidad de concretar sus sueños de riqueza y ascenso social. De esta manera, la provincia se configuró como un espacio pluricultural y pluriétnico, ${ }^{17}$ debido a la convergencia de grupos humanos de más de treinta nacionalidades, con un predominio de las nacionalidades chilena, boliviana y peruana, y por la presencia indígena, la cual representaba hacia 1878, el $43,7 \%{ }^{18}$

Desde el punto de vista eclesiástico, la Guerra del Pacífico presentó una serie de dificultades, ya que en Chile al no existir una Vicaría Castrense ${ }^{19}$ los regimientos que salían del territorio nacional no poseían ningún eclesiástico chileno que tuviera jurisdicción sobre él, y quedaba sujeto al obispo del territorio invadido. ${ }^{20}$ Sumado a esto, con la muerte del Arzobispo Rafael Valentín Valdivieso ${ }^{21}$ en 1878, las facultades eclesiásticas castrenses

15 Podestá Arzubiaga J. 2004., "Claves para entender el desarrollo de la región de Tarapacá", Revista de Ciencias Sociales, 14:22.

${ }^{16}$ González Miranda, S. 1997. “Tarapacá: Región en Conflicto (1911-1929), Revista de Ciencias Sociales, 7:39.

${ }^{17}$ González Miranda, S.1991. Hombres y mujeres de la Pampa: Tarapacá en el ciclo del salitre: 25 Iquique: Impr. Iquique.

18 Pinto, J., Artazar, P., Valdivia, V. 2003. "Patria y clase en los albores de la identidad pampina (1860-1890), Historia, 36: 278.

${ }^{19}$ En el momento de desembarco de las tropas chilenas en Antofagasta y de la declaración de guerra en abril de 1879, no existía erigido canónicamente el Vicariato Castrense, el cual fue creado por la Santa Sede el 3 de mayo de 1910. Véase: González Errázuriz, J.1996. El Vicariato Castrense en Chile. Génesis histórica y canónica de su establecimiento De la Independencia al conflicto eclesiástico de Tacna (1810-1915), Santiago: Universidad de los Andes; Matte Varas, J. 1983. Historia del Vicariato Castrense en Chile (1811-1911), Santiago: s.e.

${ }^{20}$ González Errázuriz, J. 1996: 38.

${ }^{21}$ Nació en Santiago el 2 de noviembre de 1804 y falleció en la misma ciudad el 10 de junio de 1878. Se graduó de abogado en 1825 y ejerció como regidor de la Municipalidad de Santiago y diputado por el departamento de Santiago entre los años 1831-1840. Se consagró al sacerdocio en 1834. Fue nombrado rector del Instituto Nacional, decano de la Facultad de Teología al crearse la Universidad de Chile en 1842, y consagrado Arzobispo de Santiago en 1848. Durante su desempeño en el arzobispado se produjo lo que se denominó "la cuestión del sacristán", que se transformó en un grave conflicto entre la Iglesia y el gobierno del Presidente Manuel Montt. El presidente y su ministro Antonio Varas se mostraron celosos guardadores de los privilegios del Estado sobre la Iglesia y el Arzobispo, por 
para proveer el servicio religioso al Ejército chileno, que le habían sido otorgadas por la Santa Sede en $1850,{ }^{22}$ cesaron ya que, le habían sido concedidas a título personal y no transferible a su sucesor, Joaquín Larraín Gandarillas. ${ }^{23}$ De esta manera, con el avance de la Guerra del Pacífico y las operaciones militares, los diversos pueblos de la provincia de Tarapacá, iban quedando sin atención espiritual. Así lo manifiesta el Pbro. Martín Rücker Sotomayor, en artículo publicado por La Revista Católica:

"Durante largos años vegetó en una inactividad casi absoluta. La construcción de uno que otro templo; la visita de algún Prelado; las fiestas tradicionales de algún santuario, al que asistían gran concurso del pueblo: fuera de estos hechos no hay gran cosa que referir". ${ }^{24}$

Frente a la demanda de proveer atención espiritual a la provincia, se comenzó a gestionar la creación de un Vicariato Apostólico, lo cual se materializó el 6 de abril de 1882, a través del Delegado Apostólico Monseñor Mario Mocenni. La jurisdicción del nuevo Vicariato, se extendería a todos los lugares de la provincia de ese mismo nombre ocupados por las armas chilenas, recayendo la jurisdicción parroquial en la persona del Capellán Camilo Ortúzar. Tras años de problemas jurídico-canónicos - debido principalmente a que las parroquias de la provincia seguían dependiendo directamente de la Santa Sede, ejerciendo en ellas como Ordinario eclesiástico el Delegado Apostólico en Lima - y otros tantos de organización, en 1911, fue designado como nuevo Vicario Apostólico de Tarapacá, el Pbro. José María Caro Rodríguez, quien poseía una sólida preparación académica - teológica, primero en el Seminario de Santiago y luego en el Colegio Pío Latino y la Universidad Gregoriana donde obtuvo el grado de Doctor en Teología.

su parte, fue intransigente en no tolerar la intromisión del poder civil en cuestiones meramente eclesiásticas. Fuentes, J., Cortes, L., Castillo, F., Valdés, A. 1978. Diccionario Histórico de Chile, Santiago: Editorial del Pacífico.

22 Mediante el decreto "Suplicatum est" del Papa Pío IX de fecha 20 de junio de 1850 se otorgaba facultades castrenses a Monseñor Valdivieso con el fin de proveer el servicio religioso al Ejército chileno, por catorce años, los cuales fueron renovados el 23 de marzo de 1866 por doce años más, cumpliendo en la práctica como Vicaría Castrense. Cfr. J. Matte Varas, J.1980. "Presencia de los capellanes castrenses en la Guerra del Pacífico". Historia, 15: 223.

${ }^{23}$ Nació en Santiago en 1929 y falleció en San Bernardo en 1897. Se graduó de abogado en 1845 y fue ordenado presbítero en 1847. Fue vicario capitular y en tal carácter gobernó la Iglesia de Santiago desde la muerte del Arzobispo Valdivieso hasta el nombramiento de Monseñor Mariano Casanova. El Papa León XIII lo invistió en el cargo de arzobispo titular de Anazarba. En 1888 ayudó a Mariano Casanova a fundar la Universidad Católica de Chile, de la cual fue su primer rector. Fuentes, J., Cortes, L., Castillo, F., Valdés, A.: 1978: 302.

${ }^{24}$ Rücker Sotomayor, M. 1910. "El Vicariato Apostólico de Tarapacá", La Revista Católica, 17 de septiembre, № especial: 467. 
Su designación no estuvo ajena a cuestionamientos, debido principalmente a que el contexto social y político, había fortalecido, por un lado, la toma de conciencia proletaria en la provincia, y por otro, la propagación de corrientes antirreligiosas. A este escenario, se sumaban los graves problemas sociales que padecían los obreros del salitre. Sin embargo, a su llegada al Vicariato contaba con la experiencia y conocimientos de la realidad regional, ${ }^{25}$ debido a su labor pastoral como presbítero de Mamiña, por lo cual intentó rápidamente, como otros obispos chilenos, contrarrestar el influjo anticlerical abrazando el uso de los medios de comunicación y favoreciendo la Buena Prensa.

En este aspecto, su apuesta participaba de las ideas que circulaban en su tiempo. Desde la década de 1840, la jerarquía eclesiástica chilena a través de La Revista Católica, comenzó a difundir concepciones y experiencias del catolicismo europeo en el plano social, con el fin de acercar al clero y civiles a la Doctrina Social de la Iglesia. Paralelamente, dicha revista comienza de forma sistemática a incentivar la creación de nuevos periódicos católicos en las diferentes provincias del país apelando a que la prensa católica era:

"[...]el atalaya que da el grito de alarma apenas asoma el peligro; ella también es la primera que desciende al campo de la lucha y con nutrido fogueo disipa á los enemigos o los detiene en su avance ó, por lo menos, los debilita y hace menos terribles sus invasiones. La Prensa también, cual cuerpo de zapadores, va delante de toda empresa católica, preparando el camino, destruyendo obstáculos y conquistando la cooperación necesaria para llevarla á cabo. Sin ella, en los tiempos actuales, es imposible realizar proyecto alguno de resultados valiosos para nuestra causa $[\ldots]^{\prime 26}$

Así, la importancia de tales periódicos radicaría en que,

"[...] ellos son los encargados de difundir en el pueblo de sus respectivas provincias ó departamentos las ideas cristianas y de defenderlas de los ataques de que son objeto en las mismas localidades; ellos también deben proteger á aquellas personas calumniadas ó difamadas, cuyo desprestigio refunde en prejuicio de la causa; á ellos les corresponde formar y robustecer la opinión católica en toda clase de cosas, y ciertamente harían un bien muy grande estando bien dirigidos y servidos $[\ldots]^{\prime 27}$

${ }^{25}$ Castro, L.:2005: 69.

${ }^{26}$ s/a. 6 de noviembre 1909. "La prensa Católica", La Revista Católica 199: 527.

27 Ibídem: 530. 
El Vicario Caro, consciente de sus beneficios e inquebrantable poder, emprendió la tarea en primer lugar, de dotar a la provincia de una publicación que defendiera la religión católica de los ataques del ateísmo militante, del laicismo masónico y de las concepciones revolucionarias de los socialistas. Ésta fue la misión del periódico La Luz. A esta primera publicación, se sumó otra, centrada principalmente en ofrecer una propuesta católica a los problemas sociales. De ahí el nombre del semanario Las Cuestiones Sociales, que fue editado entre los años 1921 y 1927, y que tuvo como director al presbítero Antonio Martínez, quien antes había dirigido La Luz y además, era representante en la zona de los periódicos de sesgo católico El Diario Ilustrado de Santiago y La Unión de Valparaíso. ${ }^{28}$

Paralelo a esta tarea, debió trabajar en pro de la adecuación de la Iglesia Católica de Tarapacá, a los cambios sociales que surgieron en la minería del salitre. Este ajuste no fue nada fácil debido principalmente a que su presencia en los lugares más densamente poblados fue durante largo tiempo muy precaria y a que su injerencia y gravitancia en la sociedad tarapaqueña fue exigua, adscribiéndose a una acción pastoral que se reducía a visitas esporádicas e intermitentes a las diferentes oficinas salitreras, puertos, pueblos y caletas, lugares en donde se desenvolvía sin freno la diversión y los vicios, como también las propagación de corrientes liberales, anárquicas, socialistas y masónicas provocando que la existencia y permanencia de la Iglesia, fuese fuertemente cuestionada. ${ }^{29}$

La influencia de la masonería en Chile se remonta al proceso independentista, pero su acta de nacimiento data de 1850, caracterizándose por ser una forma de sociabilidad ligada en su mayoría a comerciantes y artesanos extranjeros de origen europeo no hispano, y a norteamericanos. Este último factor explica su proliferación en las ciudades porteñas, centros del comercio nacional e internacional del Pacífico. ${ }^{30}$ En este sentido, la actividad portuaria de Iquique hacia fines del siglo XIX era significativa puesto que al ser elevado a Puerto Mayor tenía la posibilidad de franquear directamente la totalidad de los productos provenientes del extranjero, evitando su paso por Arica. Sumado a ello, en agosto de 1856, fue designado como puerto de depósito y de tránsito para Bolivia, posibilitando la exportación no sólo de salitre sino que también productos no tradicionales como lana de alpaca, bórax, oro en polvo y pepitas e incluso chocolate. ${ }^{31}$

${ }^{28}$ Castro, L.:2005:70.

${ }^{29}$ García Vázquez, P. 2001. "Pensamiento y desarrollo de la cuestión social en la Iglesia de Iquique, años 1900-1933”, Tarapacá, Revista de Historia Regional, $1: 13$.

${ }^{30}$ Del Solar, F. 2010. "La Francmasonería en Chile: de sus orígenes hasta su institucionalización”, Revista de Estudios Históricos de la Masonería, 2: 9.

31 Donoso, Rojas, C. 2003. "El Puerto de Iquique en tiempos de administración peruana", Historia, 36:134.

Hispania Sacra, LXV

Extra II, julio-diciembre 2013, 359-386, e-ISSN: 1988-4265, doi: 10.3989/hs.2013.045 
El intenso tráfico comercial generado tras la apertura del Puerto Mayor y el incremento de su población permitió que la Francmasonería se instalara en Iquique a través de la fundación de la Logia Francisco Bilbao $\mathrm{N}^{\circ} 23$, autorizada para trabajar en noviembre de $1885 .{ }^{32}$ A ésta se sumarán otras logias de lengua inglesa, tales como la Logia Pioneer $N^{\circ} 643$, fundada por la Gran Logia de Escocia en 1883 siendo sus fundadores miembros de la Logia peruana Progreso $\mathrm{N}^{\circ} 28$ que trabajaba el rito York en castellano. ${ }^{33}$ De esta manera, se va constituyendo una forma de sociabilidad en las respectivas comunidades locales, ${ }^{34}$ marcada por una fuerte crítica a la influencia de la Iglesia Católica, no sólo por haber creado un fuerte sentimiento religioso en la población, sino que además el arraigo del más cerrado fanatismo, cuyas manifestaciones ostensibles las constituían los numerosos días festivos, las fiestas religiosas y las procesiones rogativas, en donde el pueblo creía a pie y juntillas en los milagros que se atribuía a las imágenes religiosas.

La constante crítica al mundo católico y su jerarquía llevó a que José María Caro emprendiese el trabajo de escribir un libro sobre la masonería, alentado por el Capellán de Ejército de origen español, Pbro. Valentín Lete Sáenz. El propósito de éste era:

"poner al alcance del mayor número de personas, sean o no sean masones, cosas que no pueden menos de interesarles; pues creo que todos los padres de familia católicos, a todos los jóvenes y señoritas, a toda persona que tome a pechos su Religión, su patria y el bienestar de la humanidad entera, les conviene saber algo de lo mucho que ignoran sobre la institución y sobre doctrinas que tienen íntima relación con asuntos de tan vital importancia como son esos". Esgrimiendo que la masonería "[...] con su sistema de engaños y fingimientos, está deformando esas bellas cualidades ¿Qué otra cosa puede resultar en una escuela en que se dice que no se ataca ninguna religión ni se trata de política, para atacar más a fondo la religión católica y asegurar el predominio político? o se dice que la Masonería cree en Dios, siendo su trabajo de borrar su nombre en la memoria de los hombres ¿No proclama la libertad para conseguir llegar a la más opresora tiranía, como es la de las conciencias? Y así de tantas otras cosas, podría decir lo mismo [...] La Masonería, por otra parte, es contraria al patriotismo, esa virtud tan chilena, fuente de tantos heroísmos y de tantos beneficios que el

32 García Valenzuela, R. 1997. Introducción a la Historia de la Francmasonería en Chile: 169. Santiago: Eds. de la Gran Logia de Chile.

${ }^{33}$ Couyoumdjian, J.R.1995. , "Masonería de habla inglesa en Chile: algunas noticias", Boletín de la Academia Chilena de la Historia, 105: 194.

${ }^{34}$ Ibídem 196. 
ardiente amor a la Patria ha producido en nuestra vida social $y$ política". ${ }^{35}$

Al recordar en sus memorias la publicación de este libro señala que fue de gran utilidad en Chile, pero que sin embargo le significó merecer de los Hermanos Masones de Iquique el título de "Obispo viperino" y que esos mismos hermanos organizaran su entierro simbólico del cual sacaron fotografías. $^{36}$

\section{LEJOS DE LA POLÍTICA, CERCA DE LA FAMILIA}

Las razones que llevaron al Vicariato a abordar perentoriamente el tema de la familia, se encontraban íntimamente ligadas a su concepción del orden social, el cual, concebía que la regeneración de la sociedad y la consecución de paz, orden y porvenir del pueblo, sólo sería efectivo, si se comenzaba por el principio, por regenerar los fundamentos de la sociedad y de la personalidad humana. ${ }^{37}$ En este sentido, uno de los fundamentos naturales de esta última, era el derecho de asociación, ya que el hombre había sido hecho para vivir asociado con sus semejantes, debido a que sin el concurso de los demás no podía siquiera llegar a la vida, no podía desarrollar su cuerpo y sus facultades, ni conseguir ningún bien de importancia. ${ }^{38}$ Dentro de esta concepción, la familia se configuraba como la asociación por excelencia, debido principalmente, a que era el primer núcleo social perfecto y la célula fundamental en la que se formaban las sociedades humanas, ${ }^{39}$ pero además, era el espejo de toda sociedad y "todo orden, todo bienestar social se apoyaba sobre ella". ${ }^{40}$ Por esta razón, se sostenía que la regeneración del pueblo pasaba por regenerar la familia, ${ }^{41}$ ya que un hogar bien constituido y organizado era necesario y vital para construir una sociedad digna y honrada. ${ }^{42}$

Por ello, el prelado fue enfático en reconocer y denunciar que el malestar general imperante había calado tan en lo hondo de la sociedad, que su principal fundamento, la familia "se ha visto asolada por la inquietud y la angustia". ${ }^{43}$ A su entender, la descomposición familiar había llegado a tal magnitud que proliferaban escenas desgarradoras y silenciosas de dolor, las

35 Caro Rodríguez, J.M. 1924. Descorriendo el Velo. La Masonería: 2 Santiago: Editorial Sinopsis.

${ }^{36}$ Fuenzalida Morandé, J. 1968: 72.

${ }^{37}$ Las Cuestiones Sociales, 10 de noviembre 1921 37:1.

${ }^{38}$ Las Cuestiones Sociales, 31 de Marzo 1921 6: 3.

${ }^{39}$ Las Cuestiones Sociales, 5 de octubre 1921 82:1.

${ }^{40}$ Las Cuestiones Sociales, 12 de Mayo 1921 12:2.

${ }^{41}$ Las Cuestiones Sociales, 27 de Octubre 1921 35:1.

42 Las Cuestiones Sociales 12 de Mayo 1921 12: 2.

${ }^{43}$ Las Cuestiones Sociales, 7 de junio 1921 19:1.

Hispania Sacra, LXV

Extra II, julio-diciembre 2013, 359-386, e-ISSN: 1988-4265, doi: 10.3989/hs.2013.045 
cuales eran palpadas más duramente por los obreros, que se encontraban sin hogar y la mayor parte de ellos se veían privados de aquellas legítimas satisfacciones, sencillos e inocentes goces que proporcionaba la familia, necesarios para despertar y conservar sentimientos de rectitud y bondad. ${ }^{44}$ Frente a este diagnóstico, el Vicariato tarapaqueño identificó que la raíz del problema radicaba, en un conjunto de males que incubaba la sociedad:

Primero, la descomposición de lo que se llamó "el espíritu familiar", es decir, los lazos de hermandad y fraternidad, habían desaparecido a causa del imperante individualismo en que vivía la sociedad, en donde "cada uno quiere gozar sin preocupaciones de los demás". ${ }^{45}$ Segundo, como la justicia y caridad, se encontraban ausentes de la realidad, la inquietud, la angustia y la falta de recursos, habían asolado a los padres de familia. ${ }^{46}$ Tercero, la desorganización familiar, fomentada por la ideología socialista, que "pretendía la disolución del vínculo conyugal, el amor libre". ${ }^{47}$ Cuarto, las degradantes relaciones socio-económicas imperantes en el país, las cuales lejos de enmarcarse en la justicia social, fomentan el trabajo industrial y callejero de mujeres y niños. ${ }^{48}$ Quinto, los vicios, tales como el alcoholismo, habían provocado que los jefes de familia abandonaran el hogar, dejando a sus familias en medio de la más cruel miseria. ${ }^{49}$ Sexto, la responsabilidad del correcto desarrollo familiar no sólo era competencia de la Iglesia Católica, la cual "ha rodeado en todo tiempo al hogar de tanto respeto y le ha comunicado tanta fuerza moral" ${ }^{50}$ sino que también al Estado, el cual aún, frente a la persistencia del problema, se mantenía al margen de otorgar una asistencia adecuada a las familias de los obreros.

El conjunto de los problemas expuestos, llevaron a señalar que la descomposición familiar se hacía tan evidente que "ya pocos son los que no se dan cuenta de la triste realidad; poquísimos los que no la sienten también en mayor o menor grado", ${ }^{51}$ y en consecuencia, "la condición del obrero en esta crisis, ponía en manifiesto la importancia social de la familia bien organizada", ${ }^{52}$ para darle una mayor estabilidad y potenciar sus lazos familiares, pero también, para desarrollar en el obrero, las cualidades que en él existían, y sanear "en lo posible" sus defectos sociales y morales.

${ }^{44}$ Caro Rodríguez, J.C. 15 de agosto 1925. "Memorial a los señores salitreros con motivo de los sucesos de San Gregorio", La Revista Católica 575:241.

${ }^{45}$ Las Cuestiones Sociales, 12 de mayo 1921 12:2.

${ }^{46}$ Las Cuestiones Sociales, 7 de Junio 1921 19:1.

47 Las Cuestiones Sociales, 31 de Marzo 1921 6: 1.

48 Las Cuestiones Sociales, 21 de Abril 1921 9:1.

${ }^{49}$ Las Cuestiones Sociales, 24 de Noviembre 1921 39:1.

${ }^{50}$ Las Cuestiones Sociales, 12 de Mayo 1921 12:2.

${ }^{51}$ Las Cuestiones Sociales, 7 de Junio 1921 19: 1.

52 Las Cuestiones Sociales, 11 Agosto 1921 24:1. 
Debido a la envergadura de la problemática las soluciones propuestas se enmarcaron dentro de la obra "Acción Social Católica", la cual a juicio del Vicario, permitiría mantener la paz social, condición indispensable para la felicidad de los pueblos y la prosperidad de la Religión, procurando eficazmente el bienestar de una gran parte de los hombres que sufren indebidamente a causa del desconcierto económico y religioso-moral que impera en el mundo, permitiendo además, conservar en las masas populares la fe, constantemente impugnada por los enemigos de la Iglesia, especialmente los socialistas. ${ }^{53}$

Con el inicio de esta obra, una de las primeras tareas realizadas fue describir el método católico para enfrentar correctamente esta situación de degradación social y familiar, adscribiéndose así a un método teóricopropositivo denominado "Cristianismo Práctico", el cual partía de la base de la "restauración de todas las cosas en Cristo", es decir, implantar entre los hombres un cristianismo integral, práctico y universal, que comenzara por cada miembro de la sociedad y se extendiera a las familias, escuelas, leyes, relaciones comerciales, relaciones de patrones y obreros, de gobernantes y súbditos. ${ }^{54}$ La finalidad de este método era facilitar una concordancia efectiva entre las relaciones sociales, la justicia y la caridad, anteponiendo a todas las conveniencias del momento las de la verdad y de la legalidad, las del respeto a todos los derechos; y que, por fin, "alumbre con sus doctrinas las oscuridades del camino y la ceguera de los que llevan la dirección de los movimientos sociales". ${ }^{5}$

Este plan de reforma integral se configuraba como una respuesta Católica desde la misma Iglesia a combatir con todo medio justo y legal: las ideologías anticristianas y reparar por todos los medios los desórdenes que de ella derivaban; lograr que la religión volviera a las familias, a las escuelas y a la sociedad, restableciendo el principio de autoridad humana como representante de Dios; asumir como bandera propia los intereses del pueblo, y particularmente de la clase obrera, no sólo infundiéndole los principios religiosos, sino también tratando de mejorar su condición económica; y procurando por tanto, que las leyes políticas se enmarcaran dentro de la justicia social y corregir o suprimir las que se oponen a ella.

\section{LA FAMILIA, BALUARTE DE LA SOCIEDAD CATÓLICA}

El Vicariato Apostólico de Tarapacá, inmerso en la Acción Social Católica - fundada en la caridad cristiana y la justicia social- debía ayudar, a procurarles a los obreros y sus familias "aquel bienestar que deseamos para

${ }^{53}$ Caro Rodríguez, J.M. 20 de Mayo 1916. "Circular sobre la dirección de la Acción Social Católica”. La Revista Católica 355: 778-779.

${ }^{54}$ Caro Rodríguez, J.M. 3 de Junio 1922. "Orientaciones sociales señaladas por los Sumos Pontífices a los católicos". La Revista Católica, 500:846.

${ }^{55}$ Las Cuestiones Sociales, 23 de Febrero 1921 1:4.

Hispania Sacra, LXV

Extra II, julio-diciembre 2013, 359-386, e-ISSN: 1988-4265, doi: 10.3989/hs.2013.045 
nosotros mismos en la vida que hacemos en medio de la sociedad". 56 Para ello, la renovación de la sociedad, mediante un "cristianismo práctico" debía extenderse a todas las actividades humanas, ${ }^{57}$ debiendo trabajar por todos los medios que estuvieran al alcance, para que la familia fuera verdaderamente cristiana. Pero también, era necesario establecer una solución legal mucho más estricta, con respecto al cuidado y protección que el padre de familia debía a su mujer y sus hijos; perseguir las uniones adúlteras que arrojaban a las calles a una multitud de huérfanos y de niñas abandonadas, que podían llegar a ser un gran amenaza para la moral del pueblo. De ello se desprende, que la solución a la desintegración familiar no sólo era un deber de la Iglesia Católica, sino que también era un deber fundamental del Estado, ya que:

"Si nuestros legisladores inspirándose en altos deberes de amor patrio dictaran leyes para proteger a la familia contra los avances de la inmoralidad y la multiplicación de divorcios, que son un atentado contra la organización de la familia; si reconocieran y dieran valor legal al matrimonio católico; si reprimieran con severas leyes el alcoholismo, el libertinaje callejero y la propaganda inmoral en los espectáculo públicos; si dictaran leyes para extirpar de raíz las viviendas antihigiénicas, ioh! De cuantos males y plagas sociales se vería libre nuestro pueblo". 58

Ésta era la gran obra de salvación que "todos los ciudadanos sin distinción de clase ni colores" ${ }^{\text {"59 }}$ debían comprender y que el Vicariato, asumió y difundió, como estudio imprescindible, en su Semanario Las Cuestiones Sociales, señalando:

"Las Cuestiones Sociales no pueden prescindir de este estudio, porque la familia es la célula fundamental de que se forman las sociedades humanas y es indispensable dirigir bien esa institución, que reconoce a Dios como autor, si queremos obtener los grandes ideales que imponen la Religión y la Patria [...]". 60

Para lograr este acometido, el Vicariato, desplegó su accionar hacia un programa social que incluía cuatro tareas bien definidas: clarificar los principales fundamentos sobre los cuales debía constituirse la familia; determinar el rol del hombre y la mujer en la familia; inculcar los deberes y defender los derechos de la familia; y finalmente, fomentar la educación de los hijos como misión fundamental de la familia.

\footnotetext{
${ }^{56}$ Las Cuestiones Sociales, 7 de Abril 1921 7:1.

${ }^{57}$ Caro Rodríguez, J.M.:10 de Noviembre 1921: 853.

${ }^{58}$ Las Cuestiones Sociales, 10 de noviembre 1921 37:1.

59 Ídem.

${ }^{60}$ Las Cuestiones Sociales, 5 de Octubre 1922 82: 1.
} 


\section{a. Constitución de la familia}

Para la Doctrina Cristiana Dios es el autor de la sociabilidad humana, "creando la naturaleza del hombre con aptitudes y con necesidades que lo hacen buscar la cooperación de los demás para conseguir toda suerte de bienes". ${ }^{61}$ En este sentido, Él era el autor de la Sociedad Civil, dando los elementos, entre los cuales, la autoridad era tan esencial como la multitud que se une en persecución del bien común temporal. Pero también, era el autor de la Sociedad Doméstica: la familia, creando los elementos que lo constituyen, la inclinación y aptitudes para el matrimonio, su fin y sus leyes esenciales.

Esta sociedad doméstica, dependiente de las leyes naturales, tenía por principio y fundamento el matrimonio, el cual había sido revestido de un carácter sagrado y para el cristiano constituía una institución divina, elevada a la dignidad de sacramento. ${ }^{62}$ Por esta razón, no podía ser "despreciado o prescindir de él en sus relaciones con el otro sexo". ${ }^{63}$ El matrimonio, señalaba el Vicariato, desde la antigüedad había estado sometido a las leyes civiles, aunque "en realidad los pueblos más cultos lo consideraban como un rito religioso, en los cristianos produce la gracia sacrificante, y como es verdaderamente sagrada, depende de la autoridad religiosa en todo lo esencial". ${ }^{64}$ Por esta razón, la familia, tenía el derecho de constituir un matrimonio conforme a las leyes civiles y también a las leyes de la Iglesia Católica.

Según las leyes religiosas, el matrimonio o sociedad conyugal, tenía por derecho natural, dos propiedades esenciales: unidad e indisolubilidad. ${ }^{65}$ Al ser uno, excluía la pluralidad de maridos y mujeres, y al ser indisoluble, excluía el divorcio. ${ }^{66}$ De esta manera, la poligamia, el divorcio y el amor libre, se configuraban como acciones contrarias a los valores propiamente cristianos, ya que el amor entre los esposos, perfeccionado mediante el sacramento del matrimonio, exigía, por su misma naturaleza, la unidad e indisolubilidad, para cumplir, por un lado, con el Plan Divino. ${ }^{67} \mathrm{Y}$ por otro, también responder a los derechos de los hijos. Esta concepción de la constitución familiar, que difundía e inculcaba el Vicariato, era la única vía efectiva para evitar, tanto la degradación moral, como religiosa de la sociedad.

\footnotetext{
${ }^{61}$ Las Cuestiones Sociales, 23 de Febrero 1921 1: 2.

62 Las Cuestiones Sociales, 30 de Junio 1921 18:3.

${ }^{63}$ Las Cuestiones Sociales, 31 de Marzo 1921 6: 4.

${ }^{64}$ Las Cuestiones Sociales, 5 de Octubre 1922 82:1.

${ }^{65}$ Las Cuestiones Sociales, 28 de Abril 1921 10:1.

${ }^{66}$ Las Cuestiones Sociales, 5 de Octubre 1922 82:1.

${ }^{67}$ Las Cuestiones Sociales, 3 de Mayo 1922 111: 2.
} 


\section{b. Sociedad Conyugal: El rol de la mujer y el hombre}

Dentro de esta concepción cristiana del orden social, cada integrante de la sociedad doméstica- padre, madre e hijos- tenía un rango o posición determinada, en donde los hijos, tenían el deber de obedecer a sus padres; la mujer, en cuanto tal, se encontraba sujeta a su marido; y el esposo, debía de amar a su mujer. ${ }^{68}$ De esto se desprende, una concepción jerárquica de la sociedad y de la familia, en donde los miembros, eran desiguales.

El hombre, dividía su vida en dos partes: en su hogar, como jefe de la familia y en su trabajo, el cual le proveía del sustento familiar. Así, "el pensamiento del hombre de trabajo, que gira alrededor de las batallas de la vida, tendrá necesariamente que ser influenciado por la forma en que esté organizado el hogar". ${ }^{69}$ De ahí la importancia de orientarlo en sus deberes como padre y esposo: Primero, "el hombre debía constituir una familia, en donde prevaleciera el amor y fuese sostenida por los frutos de su trabajo, ya que "en una recta organización económica, recae sobre el jefe de familia la necesidad y misión de ofrecerles lo necesario para vivir convenientemente". ${ }^{70}$ Para esto, era necesario "que la ordinaria retribución del jefe de familia alcance a lo menos para el sustento del hogar". ${ }^{71}$ Segundo, debía ser prudente en los negocios, intentando que existiera siempre un superávit en los efectos y en los intereses. Para ello, debía destruirse todo error y desorden doméstico, como el alcoholismo, que significaba la destrucción moral, intelectual y material de la familia "[...] debe impedirse que con el ejemplo propaguen el vicio, que empleen malamente el dinero sustraído al bienestar del hogar y que preparen con sus hábitos herencias de deformidad físicas y morales". ${ }^{72}$ Tercero, debía brindar a su esposa un inacabable apoyo moral, buscando en ella consuelo, sin desoír sus consejos y nunca "cometer la torpeza de presentar en oposición o lucha el poder paterno con el materno". ${ }^{73}$ Cuarto, intentar que los hijos pudiesen sobrellevar los males de la vida. Para esto, debía lograr por un lado, que los hijos vieran en él, cuando niños, una fuerza que los amparara; cuando adolescentes, una inteligencia que les enseñara y cuando hombres, un amigo que les aconsejara; y por otro lado, debía lograr un estudio detenido de las aptitudes de los hijos, "para que no le des a comprender que puede ser más que tú, pero ponle, silenciosamente en camino para serlo". ${ }^{74}$ Y por último, debía cuidar que los hijos fueran tan robustos de cuerpo como sanos de inteligencias, sólo así, los hijos llegaría a ser buenos antes de ser sabios.

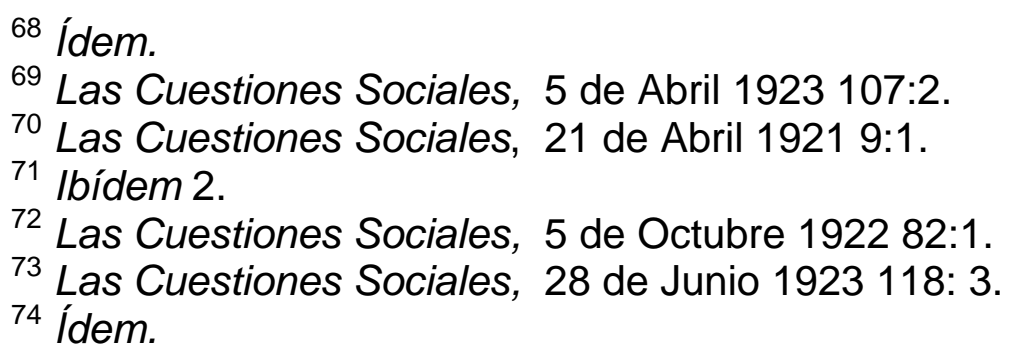


Esta visión del hombre, estaba marcada por una fuerte tendencia a sobrevalorar su rol de hombre proveedor, capaz de brindar a su familia el sustento material, y con ello contribuir al bienestar social. Por su parte, la mujer casada, debía cumplir deberes esenciales con su marido y sus hijos, y por sobre toda otra consideración, debía:

"[...] ser la "mujer fuerte" en las situaciones difíciles de la vida la esposa cariñosa, dulce y comprensiva, la madre amorosa que vele a su pequeño hijo, enseñándole conjuntamente a conocer a Dios, amar a su patria y respetar a sus mayores, y por fin llenar su otra misión, sino tan espiritual como las anteriores, no por ello menos importante, y es ser buena ama de casa, limpia y hacendosa; cumpliendo todos estos deberes seguramente su hogar será feliz, alejará al esposo de la taberna y sus hijos serán sanos de alma y cuerpo[... " . ${ }^{75}$

Dentro de esta concepción, la mujer era la portadora y propagadora de las tradiciones, guiando y entregando las herramientas morales, religiosas, sociales y cívicas durante los primeros años de vida de los hijos, y luego en su juventud, contribuía a evitar los males y vicios que podían afectar a sus hijos. Por ello, la férrea defensa del Vicariato tarapaqueño por suprimir el trabajo industrial de las mujeres, ya que:

"[...] La madre no puede preocuparse de su hijo, tiene que abandonarlo a una vecina que quiera darle, cuando pueda unas pobres sopas, y si alcanza el uso de la razón pasará el día en la calle con compañeros que le enseñarán toda clase de maldades. De aquí esa mortalidad que asusta, una creciente degeneración de la raza y la completa ausencia de moral". ${ }^{76}$ La mujer, desde el momento que se convertía en obrera, dejaba de ser mujer, ya que: "En lugar de una vida recogida, púdica, rodeada de caras afecciones, tan necesarias a su felicidad como a la nuestra, vive bajo el yugo de un contramaestre, en perpetuo contacto con hombres de una moralidad dudosa y lejos de su marido e hijo". ${ }^{77}$

Para evitar la destrucción familiar, que podía acarrear el trabajo femenino, se promovía una serie de cualidades que debía poseer una buena madre: debía practicar la reflexión, a través de la cual podía ver claramente que había que hacer y cómo había que hacerlo, ya que sin reflexión, no existía el orden, que era necesario para la mantención del hogar. Pero también, debía desarrollar un método, que le ayudara a priorizar las labores de su trabajo doméstico, sólo así, descubriría el porvenir, inspiraría la economía y prepararía la comodidad del hogar. ${ }^{78}$ Todo esto, enmarcado

${ }^{75}$ Las Cuestiones Sociales, 8 de Diciembre 1921 41:3.

76 Ídem.

77 Las Cuestiones Sociales, 8 de Diciembre 1921 41:4.

78 Las Cuestiones Sociales, 15 de Febrero 1923 100: 3.

Hispania Sacra, LXV

Extra II, julio-diciembre 2013, 359-386, e-ISSN: 1988-4265, doi: 10.3989/hs.2013.045 
dentro de un espíritu de decisión, firmeza, vigilancia, bondad, piedad y paciencia, que llevarían a la madre de familia a "ser respetada, amada, honrada y se dirá de ella: es una gran señora. Y lo será realmente". ${ }^{79}$

\section{c. Derechos de la Familia}

Junto con sistematizar las bases en la que debía fundarse la familia y determinar los rol de los padres, el Vicariato Apostólico de Tarapacá, identificó, que los derechos de una familia dimanaban, del propio fin asignado por la naturaleza, a la sociedad familiar: unir a los esposos mediante el matrimonio y por consiguiente, "trasmitir, desarrollar y perpetuar la vida humana", ${ }^{80}$ como también, fomentar el espíritu cívico, el patriotismo y la educación. Para esto, las familias, tenían el deber de ejercitar a diario las virtudes de obediencia, orden, generosidad, honor, trabajo y abnegación, todas indispensables para el bienestar de la comunidad, ya que: " [...] Un hogar bueno es el semillero de la virtudes cívicas e individuales. Aunque esto nos parezca una idea, no es por eso imposible. Los ejemplos de fracaso no deben desalentar a nadie y deben al contrario apresurarse a aplicar el medio". 81

El medio, que se postulaba era el reconocimiento y la efectiva ejecución de los derechos de la familia, los cuales eran, imprescriptibles, anteriores y superiores a toda ley positiva: derecho a multiplicarse, derecho a ser protegida, derecho a vivir de su trabajo, derecho a la propiedad y finalmente, derecho a educación. En su violación, radicaba la degradante situación que asolaba a la sociedad tarapaqueña y por ello, la fuerte defensa desplegada por la Iglesia Católica de Tarapacá, en el periodo en estudio.

En esta defensa, el derecho a multiplicarse, significaba por un lado, cumplir con el fin supremo de la familia: la procreación de los hijos, pero por otro lado, implicaba una ayuda social, especialmente en los primeros tiempos. En este sentido, el Vicariato Apostólico, inspirado en el catolicismo francés, ${ }^{82}$ señalaba que los gravámenes de una familia numerosa recaían directamente en los padres de familia y en segundo término, en el Estado, ya que éste "veía aumentada su población, su capital, sus medios de trabajo, su defensa y su porvenir" ". Por esta razón, la familia tenía también, el derecho a ser protegida y que "el Estado los ayude a llevar la carga de las familias obreras numerosas". ${ }^{84}$

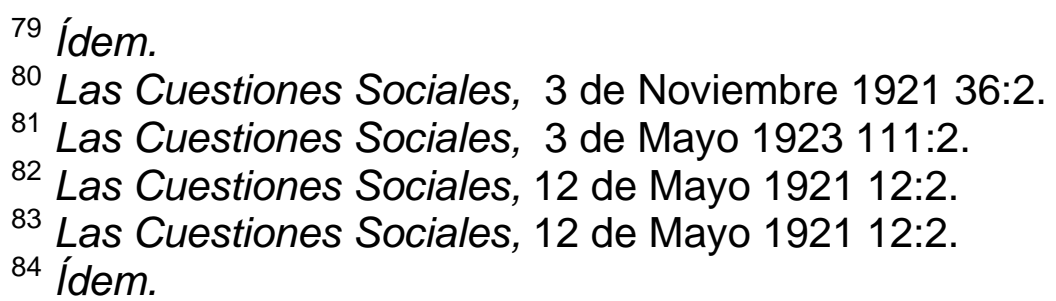


Parte importante de las soluciones propuestas por el Vicariato, para lograr, que cumplieran los derechos de la familia, radicaban en fomentar el matrimonio religioso y civil en los obreros, lo cual no podría llevarse a la práctica, sin un salario adecuado, que animara al obrero a llevar la carga del matrimonio y de su familia, ${ }^{85}$ es decir, el derecho a vivir de su trabajo y una adecuada reglamentación laboral obrera, que se adecuara a las demandas sociales de los nuevos tiempos. Por esta razón, se señalaba: "hay que ir a algo más práctico y de más seguros resultados. Hay que ir, de una vez por todas, al estudio y dictación de un Código social, tan completo como lo exigen las nuevas orientaciones que han tomado entre sí el Capital y el Trabajo". ${ }^{86}$ Para ello, era necesaria la intervención del Estado, por medios de leyes que ayudaran a mejorar la condición obrera, ya que "Las leyes pueden reglamentar las condiciones higiénicas, de las habitaciones y del trabajo, especialmente para mujeres y niños, el máximum de su duración, el mínimum del salario; pueden no sólo facilitar el ahorro, estableciendo Cajas de ahorro y de préstamos, sino también hacerlo obligatorio, pueden facilitar la mejor distribución de las tierras de cultivo; reglamentar o prohibir la venta de alcoholes o licores; establecer seguros contra accidentes, etc." ${ }^{87}$

Por esta razón, era necesario anticiparse a los acontecimientos y avocarse a buscar la armonía entre el capital y el trabajo, por medio de una legislación que resguardara los derechos de la familia. Esta propuesta surgía en reacción a la visión que, hasta ese momento, se tenía del trabajo:

"Se ha sostenido que trabajo es una mercancía, que el obrero debe ganar según la demanda o la oferta de brazos, a despecho de sus necesidades vitales, que es lícito sacar de sus fuerzas y de su actividad el mayor provecho posible sin las consideraciones humanitarias que merecen la edad, el sexo y la salud". ${ }^{88}$

Esta visión, era la causante de las injusticias, del trabajo de las mujeres y niños en fábricas y talleres, del menoscabo de la salud y la disminución de la esperanza de vida, lo cual habría desencadenado: "la desorganización de las familias obreras, el pauperismo, el abandono de las labores campesinas, la aglomeración de las masas en las ciudades, en viviendas mal sanas y estrechas, en barrios desatendidos y sucios, donde la corrupción precoz y la mortalidad infantil hacen su agosto". ${ }^{89}$

d. Misión de la familia: la educación de los hijos

${ }^{85}$ Caro Rodríguez, J.M.15 de agosto1925: 244.

${ }^{86}$ Las Cuestiones Sociales, 11 de Abril 1921 8:3.

${ }^{87}$ Las Cuestiones Sociales, 23 de Junio 1921 17: 4.

${ }^{88}$ Las Cuestiones Sociales, 10 de Marzo 1921 3:1.

89 Ídem. 
La misión de la familia radicaba fundamentalmente en la educación de los hijos, ya que ésta era la fuente de donde primero, los hijos recibían la vida, y segundo, la primera escuela de donde los hijos aprendían a pensar y a orar. Por ello, los hijos debían encontrar en la familia todo lo que necesitaban para nacer, desarrollarse física, moral e intelectualmente. Por esta razón, señalaba el Vicario, "entre los derechos de los padres de familia hay alguno que deba ser principalmente defendido, es éste, sin duda alguna, el que se refiere a la educación de los hijos". ${ }^{90}$ Las razones esgrimidas para defender férreamente el derecho a la educación, radicaba en que el deber más importante de todo padre de familia, era el de velar por la buena educación intelectual, moral y religiosa de sus hijos, ya que "[...] sin lo cual no se desarrollarían armónicamente sus facultades, ni se educarían bien sus inclinaciones y sentimientos, y querían expuestos a ser víctimas durante toda la vida de una educación mal dirigida, desequilibrada e incompleta". ${ }^{91}$

En este sentido, se reconocía y asumía que la instrucción era una de las aspiraciones más unánime de esos tiempos y por ello agregaba José María Caro: "nos parece superfluo el ocuparnos en persuadirla. Creemos que no habrá un padre o una madre de familia que no quiera darla a sus hijos, aun a costa de grandes sacrificios, como hemos tenido el agrado de comprobarlo en algunas poblaciones del interior, que, por una u otra causa no cuentan con una escuela gratuita". ${ }^{92}$ De esto se desprende, que la educación de los hijos correspondía por una parte a los padres y por otra parte a los educadores en las escuelas:

"El ideal sería que ellos solos y personalmente, el padre y la madre, educaran a todos sus hijos; porque la naturaleza los ha dotado de las cualidades que son más raras en el educador, pero se hallan distribuidas en ellos dos, de manera que su obra se complementa. Sin embargo, es muy difícil que en la práctica que se encarguen de ellos de esa tarea, a pesar de que no puede menos de ser la más agradable de todas: son tan variados los conocimientos y es tan intensa la actividad que exige la vida contemporánea. De ahí el que se vean obligados a buscar maestros que hagan sus veces". 93

Pero, como el derecho de los padres de familia era inalienable, al ser al mismo tiempo derecho y deber, ninguna autoridad humana podía imponerles el maestro que instruyera a sus hijos, ni la escuela o colegio, en el que fueran a educarse, como tampoco, podían imponerles textos ni autores contrarios a su conciencia. De esta manera, haciendo uso de su derecho a

90 Las Cuestiones Sociales, 5 de Octubre 1922 82: 2.

${ }^{91}$ Caro Rodríguez, J.M. 17 de Mayo 1913. "Pastoral sobre el deber procurar la educación cristiana de la niñez y juventud". La Revista Católica, 283: 869.

92 Ibídem 869.

${ }^{93}$ Las Cuestiones Sociales, 5 de Octubre, 1922 82:2. 
elegir, también debían exigir su derecho a vigilar o rechazar, lo que a su juicio, fuese pernicioso para sus hijos. Con esta visión de la educación, se refutaba la creencia, que al Estado le correspondía las principales atribuciones en lo referente a la educación, por esta razón, enfáticamente se señalaba:

"El Estado no tiene derecho alguno de inmiscuirse en la familia si no es para mantener derechos que de otro modo no puedan ser mantenidos. Los hijos, mientras no llegan a su completo desarrollo, pertenecen a los padres por ser como parte y continuación de éstos mismos. Los padres son los educadores naturales de su prole, a la que están unidos con los más fuertes lazos del afecto. Todos uniformemente debemos reverenciar el recinto sagrado del hogar y no penetrar en él sin permiso. El Estado no tiene derecho alguno para atribuirse el cuidado del hijo sino es en el caso de inhabilidad o descuido de los padres". ${ }^{94}$

Identificando que la misión del Estado era "[...] estimular y obligar a los padres reacios en el cumplimiento de sus deberes educacionales o suplir su negligencia y de ningún modo usurpar sus derechos. Es necesario no olvidar que antes del Estado con prioridad de tiempo y de naturaleza, existe la familia y que las familias se han juntado y han constituido estados sólo para su mayor bien". ${ }^{95}$ Con ello, en ningún momento, el Vicariato Apostólico de Tarapacá, se mostraba enemiga de la instrucción del Estado, ejemplo de ello, son las palabras de su Vicario:

"Por lo que a Nós toca, profesamos gratitud y estimación y honramos debidamente a los maestros o maestras del Estado, de cualquier categoría que sean, que cumplen bien sus deberes. Afortunadamente los hay aún entre nosotros, y de su competencia y esfuerzos rinden testimonio el adelanto de los alumnos, el cariño que profesan a sus maestros y la gratitud de sus padres". ${ }^{96}$

El "cumplir bien con sus deberes", implicaba impartir una educación que no abandonara las enseñanzas religiosas. De esta manera, lo que condenaba era: "esa instrucción pérfida que, cubierta con el velo de una ciencia más aparente que real y a veces apenas con el sólo nombre de ciencia hostiliza la verdad revelada: lo que la Iglesia condena es esa guerra a sus enseñanzas, que se le hace bajo el disfraz de enseñanza del Estado, como si el Estado que manda enseñar la Religión, mandara también enseñar la antirreligión". ${ }^{97}$ Las razones por las cuales se llamaba a anteponer por sobre todo la instrucción religiosa, iban más allá de cumplir su misión

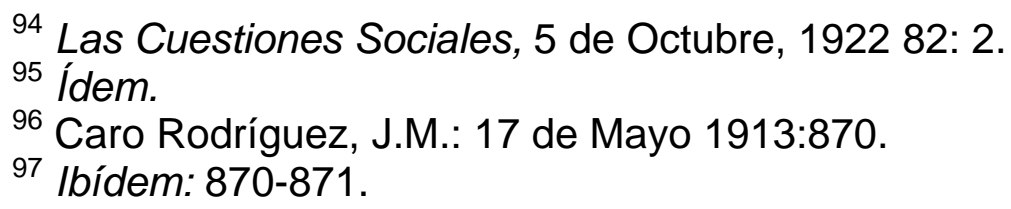

${ }^{94}$ Las Cuestiones Sociales, 5 de Octubre, 1922 82: 2.

95 Ídem.

${ }^{96}$ Caro Rodríguez, J.M.: 17 de Mayo 1913:870.

97 Ibídem: 870-871.

Hispania Sacra, LXV

Extra II, julio-diciembre 2013, 359-386, e-ISSN: 1988-4265, doi: 10.3989/hs.2013.045 
sacerdotal, sino que radicaban en la profunda convicción, que a través de ella, se lograría una mejor condición para los obreros y sus familias. En este sentido, la enseñanza antirreligiosa, sería condenable por antipedagógica, por contraria a la formación intelectual y moral de los niños. $Y$ por ende, los profesores que contribuyeran a erradicar la fe en los niños serían causantes de: 1) distraer la atención de los niños, a focos perniciosos para su vida moral; 2) privar a los niños del motivo más poderosos que tenían para respetarle su autoridad y empeñarse en cumplir sus deberes escolares; 3) debilitar el respeto y estimación que todo hijo debe tener de sus padres, destruyendo la autoridad que ellos necesitan, para aconsejarlo o corregirlo. Con esta actitud, en poco tiempo, un maestro falto de fe "como desgraciadamente suele haberlos, habrá disminuido o acabado la autoridad que los padres necesitan durante largos años para procurar la recta educación de sus hijos". 98 Por esta razón, la Iglesia tarapaqueña, efectuaba un ferviente llamado a los padres de familia a instruir a sus hijos, confiados en que ninguna otra obra, podía el hombre, esperar con más seguridad el resultado de sus esfuerzos perseverantes. ${ }^{99}$

A través de estas orientaciones el Vicario José María Caro puso en marcha una reforma integral de la sociedad tarapaqueña, en la cual a la familia tenía un rol primordial, al configurarse como la institución idónea para la socialización de la moral y la vida cívica, para la mantención de las costumbres, el orden y determinadas tradiciones y donde simultáneamente las costumbre y actitudes reiteradas por la familia se transformaban en sus principales mecanismos de reproducción, al condicionar los recursos familiares, las características del matrimonio y los roles femenino y masculino.

\section{PALABRAS FINALES}

En este artículo se analizó el apostolado familiar del Vicario Apostólico José María Caro en la provincia de Tarapacá en las primeras décadas del siglo XX. Su accionar pastoral se desarrolló en uno de los más importantes epicentros de agitación y conflicto social, en donde las oficinas salitreras y las actividades económicas del puerto de Iquique permitieron la concentración de una gran y heterogénea población popular, que al igual que el resto del país, sufrió los abusos y la indiferencia política de la oligarquía, transformándose así, en un poderoso foco de atracción para el desarrollo de actividades anarquistas y socialistas.

Este escenario marcado por la precaria inserción de la Iglesia al acontecer local, llevó a que el prelado asumiera las transformaciones de la sociedad chilena y propiciara, desde un discursos católico, el desarrollo de una provincia en la que se lograra una perfecta sintonía entre las relaciones

98 Ibídem: 873.

99 Caro Rodríguez, J.M.: 17 de mayo 1913:873. 
sociales, la justicia y la caridad. Para ello asumió tempranamente un apostolado social que le permitiera acercar el Vicariato a los habitantes de la provincia, desarrollando además, de manera precursora, un programa de acción social católica edificado sobre el cristianismo práctico que hizo realidad la apertura de la Iglesia al mundo, pasando de ser una Iglesia observante a una Iglesia militante, comprometida con las familias más desposeídas.

La cuestión es importante puesto que su accionar pastoral, marcado por el celo apostólico, estuvo destinado no sólo a denunciar los males sociales del país los cuales repercutían indudablemente en las familias de la pampa salitrera que se veían asoladas por la inequidad, la inmoralidad y la injusticia producto de la desarmonía del capital y el trabajo, sino que también a desarrollar un programa de acción social , transformándose así, en uno de los pioneros en aplicar la Doctrina Social de la Iglesia en tierras nortinas.

Finalmente, este artículo permitió descubrir una impronta desconocida para muchas de las generaciones posteriores, una fuerte convicción en la Doctrina Social de la Iglesia y un compromiso con los más necesitados.

\title{
BIBLIOGRAFÍA
}

\author{
Periódico
}

Las Cuestiones Sociales, Iquique.

No 1, 23 febrero 1921; No 2, 3 marzo 1921; No 3, 10 marzo 1921; No 4, 17 marzo 1921; No 6, 31 marzo 1921; No 7, 7 abril 1921; № 8, 11 abril 1921; No 9, 21 abril 1921; No 10, 28 abril 1921; No 12, 12 mayo 1921; $N^{\circ} 14,2$ junio 1921; No 17, 23 junio 1921; No 18, 30 junio 1921; No 19, 7 junio 1921; $\mathrm{N}^{\circ} 24,11$ agosto 1921; No 28, 8 septiembre 1921; № 35, 27 noviembre 1921; $\mathrm{N}^{0} 36,3$ noviembre 1921; $\mathrm{N}^{\circ} 37,10$ noviembre 1921; No 38,16 noviembre 1921; No 39, 24 noviembre 1921; No 41, 8 diciembre 1921; No 46, 12 enero 1922; No 82, 5 octubre 1922; No 100, 15 febrero 1923; No 107, 5 abril 1923; № 111, 3 mayo 1923; № 118, 28 junio 1923; № 259, 10 junio 1926.

\section{Revista}

La Revista Católica, Santiago.

Caro Rodríguez, J.M. 17 de Mayo 1913. "Pastoral sobre el deber procurar la educación cristiana de la niñez y juventud". La Revista Católica, 283: 868 -876. 
Caro Rodríguez, J.M. 20 de Mayo 1916. "Circular sobre la dirección de la Acción Social Católica". La Revista Católica 355: 778 -781.

Caro Rodríguez, J.M. 3 de Junio 1922. "Orientaciones sociales señaladas por los Sumos Pontífices a los católicos". La Revista Católica, 500: 844 -854.

Caro Rodríguez, J.C. 15 de agosto 1925. "Memorial a los señores salitreros con motivo de los sucesos de San Gregorio", La Revista Católica 575: 241-247.

Rücker Sotomayor, M. 1910. "El Vicariato Apostólico de Tarapacá", La Revista Católica, 17 de septiembre, № especial: 465 -479.

S/a. 6 de noviembre 1909. "La prensa Católica", La Revista Católica 199: $520-528$

\section{Bibliografía}

Araneda Bravo, F. 1986. Historia de la Iglesia en Chile, Santiago: Ediciones Paulina.

Arraño Acevedo, A. 1992. De niño campesino a cardenal: (la infancia de monseñor Caro), Santiago de Chile: Zig-Zag.

Barrios Valdés, M. 1992. Chile y su Iglesia: una sola historia, Santiago: Editorial Salesiana.

Castro, L. 2005. "La cuestión social y la visión de la Iglesia Católica de Tarapacá a través del Semanario Las cuestiones sociales (1921-1927)", Revista de Ciencias Sociales, 15: 66-89.

Caro Rodríguez, J.M. 1924. Descorriendo el Velo. La Masonería: 2 Santiago: Editorial Sinopsis.

Couyoumdjian, J.R.1995. , "Masonería de habla inglesa en Chile: algunas noticias", Boletín de la Academia Chilena de la Historia, 105: 185208.

Del Solar, F. 2010. "La Francmasonería en Chile: de sus orígenes hasta su institucionalización", Revista de Estudios Históricos de la Masonería, 2: $1-15$.

Donoso, C. 2003. "El Puerto de Iquique en tiempos de administración peruana", Historia, 36:123-158. 
Figueroa, C., Silva, B. 2007. Visitas pastorales de las parroquias de la provincia de Tarapacá. José María Caro R. Obispo de Milas y Vicario Apostólico de Tarapacá (1922-1926), Santiago: LOM Ediciones.

Fuentes, J., Cortes, L., Castillo, F., Valdés, A. 1978. Diccionario Histórico de Chile: 606 Santiago: Editorial del Pacífico.

Fuenzalida Morandé, J. 1968. El cardenal Caro: autobiografía del eminentísimo y reverendísimo, señor Cardenal D. José María Caro Rodríguez Primer Cardenal chileno: apuntes y recuerdos, documentos importantes, Santiago: Arzobispado de Santiago.

Garay Vera, C. 2007. "El debate parlamentario sobre las negociaciones con Bolivia entre 1880 y 1904", Cuadernos de Historia, 27: 43-74.

García Valenzuela, R. 1997. Introducción a la Historia de la Francmasonería en Chile, Santiago: Eds. de la Gran Logia de Chile.

García Vázquez, P. 2001. "Pensamiento y desarrollo de la cuestión social en la Iglesia de Iquique, años 1900-1933", Tarapacá, Revista de Historia Regional, 1: 9-24.

González Errázuriz, J.1996. El Vicariato Castrense en Chile. Génesis histórica y canónica de su establecimiento De la Independencia al conflicto eclesiástico de Tacna (1810-1915), Santiago: Universidad de los Andes.

González Miranda, S.1991. Hombres y mujeres de la Pampa: Tarapacá en el ciclo del salitre: 25 Iquique: Impr. Iquique.

González Miranda, S. 1997. "Tarapacá: Región en Conflicto (19111929), Revista de Ciencias Sociales, 7: 38-47.

González Miranda, S. 2002. Chilenizando a Tunupa. La escuela pública en el Tarapacá andino 1880-1990, Santiago: Ediciones de la Dirección de Bibliotecas, Archivos y Museos DIBAM. Paulinas.

Huerta, M.A.1991. Catolicismo Social en Chile, Santiago: Ediciones

León XIII, Pío XI. 1931. Las enseñanzas sociales de la Iglesia: Rerum Novarum y Quadragesimo Anno: 1891-1931. Santiago: Impr. Chile.

Matte Varas, J.1980. VARAS, "Presencia de los capellanes castrenses en la Guerra del Pacífico". Historia, 15: 179-236. 
Matte Varas, J.1983. Historia del Vicariato Castrense en Chile (18111911), Santiago: s.e.

Michel, J.1989. "La huelga de jornaleros y estibadores de Iquique y la participación del presbítero don Daniel Merino Benítez, 1916", Anuario de Historia de la iglesia de Chile, 7: 161-182.

Monreal, S. 2009. "Catolicismo en el Cono Sur: genealogía de un ideario", en F. Berrios;J, Costadoat; D. García (eds), Catolicismo Social Chileno. Desarrollo, crisis y actualidad: 21-45. Santiago: Centro Teológico Manuel Larráin, Universidad Alberto Hurtado.

Mönckeberg Barros, G. 1984. Monseñor José María Caro Rodríguez 1939-1958. Séptimo Arzobispo de Santiago. Santiago de Chile: Editorial salesiana.

Oviedo Cavada, C. 1979. Los Obispos de Chile, 1561-1978. Santiago de Chile: Editorial Salesiana.

Pinto, J., Artazar, P., Valdivia, V. 2003. "Patria y clase en los albores de la identidad pampina (1860-1890), Historia, 36: 275 -332.

Podestá Arzubiaga J. 2004., "Claves para entender el desarrollo de la región de Tarapacá", Revista de Ciencias Sociales, 14: 20-35.

Salinas, A. 1981. Un pastor Santo: el eminentísimo señor cardenal don José María Caro Rodríguez (1866-1958), Santiago: Andrés Bello.

Silva, F. 1965. "Notas sobre el pensamiento social católico a fines del siglo XIX". Historia, 4: 237-262.

Stuven, A. 2009. "Cuestión Social y catolicismo social: de la nación oligárquica a la nación democrática", en F. Berrios; J, Costadoat; D. García (eds), Catolicismo Social Chileno. Desarrollo, crisis y actualidad: 47 -82. Santiago: Centro Teológico Manuel Larraín, Universidad Alberto Hurtado.

Troncoso Zúñiga, V. 2007. José María Caro y el Vicariato Apostólico de Tarapacá. Proselitismo, familia y conflicto social (1911-1926), Santiago: Tesis inédita para optar al grado de Licenciada en Historia por la Universidad del Desarrollo.

Troncoso Zúñiga, V. 2010. “Un Cruzado en Tarapacá. José María Caro y su gestión pastoral en el Vicariato, 1911-1926”, Bicentenario, 9:101-124.

Troncoso Zúñiga, V. 2012. "el modernismo religioso y la literatura latinoamericana en los albores del siglo XX" en C. Assumma; L. De Llera, La 
Primera Modernidad: El Modernismo Religioso y Literario en España e Hispanoamérica: 253-276. Bogotá: Editorial Planeta.

Uribe, M.; Sanhueza, L.; Bahamondes, F. 2007. "La cerámica prehispánica tardía de Tarapacá, sus valles interiores y costa desértica, norte de Chile (CA. 900-1.450 D.C): Una propuesta tipológica y cronológica", Chungara, Revista de Antropología Chilena, 39: 143-170.

Valdivieso Fernández, P. 1999. "Cuestión social y Doctrina social de la Iglesia (1880-1920): Ensayo histórico sobre el estado de la investigación", Historia, 32:553-573.

Valdivieso Fernández, P. 2006. Dignidad humana y justicia: la historia de Chile, la política social y el cristianismo (1880-1920). Santiago: Ediciones Universidad Católica de Chile.

Vanherk Moris, J. 1963. Monseñor José María Caro: Apóstol de Tarapacá, Santiago: Del Pacífico. 